\title{
A story of trials and tribulations
}

\section{The National Prosecuting Authority, 1998 - 2014}

\author{
Martin Schönteich* \\ mschonteich@jjay.cuny.edu \\ http://dx.doi.org/10.4314/sacq.v50i1.1
}

Established in 1998, the National Prosecuting Authority (NPA) immediately had to deal with escalating levels of serious crime. Through a variety of innovations, including prosecution-driven investigations popularised by the 'Scorpions', specialised career paths for prosecutors, a focus on performance measurement, and improved conditions of service, the NPA quickly became an employer of choice for a new generation of law graduates. Over the last 16 years, the NPA's specialised units have performed well. However, the NPA's performance at the level of the lower courts - where the vast majority of prosecutions occur - has been mixed. With the appointment of its sixth head or acting head in late 2013, the NPA has been burdened with inconsistent - and at times, poor and unsuitable - leadership. Relatedly, political interference and the politicisation of the NPA have seriously undermined a once promising institution, negatively affecting staff morale and performance and sapping public confidence in the NPA. The future of the NPA as an institution that exercises its functions without fear, favour or prejudice, as mandated by the Constitution, hangs in the balance.

This article begins with describing the decades-old struggle by South Africa's most senior prosecutors to be independent of executive interference. Unsurprisingly, the independence of the National Prosecuting Authority (NPA) played a prominent role in the debates around the establishment of a new, unified prosecution service for a post-apartheid South Africa. This is followed by an analysis of the development and growth of the NPA, focusing on its performance and the impact political interference and the politicisation of some of the NPA's leadership - has had on the organisation and its operational

\footnotetext{
* Martin Schönteich directs the National Criminal Justice Reform Programme of the Open Society Justice Initiative. He previously worked as a senior researcher for the Institute for Security Studies' Crime and Justice Programme, and as a public prosecutor for the South African Department of Justice. He is an advocate of the High Court of South Africa. He is presently enrolled at the City University of New York as a doctoral student in criminal justice.
}

effectiveness. The article is based on research the author has undertaken on the NPA for the last 15 years, ${ }^{1}$ including interviews with a cross section of NPA staff in a number of provinces in $2012-2013$.

\section{Born into controversy}

The establishment of the NPA was itself contentious. ${ }^{2}$ From the beginning of negotiations in the early $1990 \mathrm{~s}$ about South Africa's future political dispensation, control over criminal prosecutions and, related, the relationship between a new prosecution service and the political executive were contested. ${ }^{3}$ It is necessary to provide some background to the debate, as the arguably ambiguous constitutional provisions dealing with the NPA would come back to haunt the organisation as it experienced, and, at times, succumbed to, political interference. ${ }^{4}$

Since Union in 1910, South Africa's prosecutors were, to varying degrees, subjected to executive 
interference in their affairs. ${ }^{5}$ Between 1926 and 1992 , successive ministers of justice effectively controlled the attorneys-general, the country's most senior prosecutors, whose powers extended largely along provincial lines. ${ }^{6}$

In 1992, the Attorney-General Act ${ }^{7}$ sought to ensure that attorneys-general functioned independently of the executive. In terms of the Act, the authority to institute prosecutions became the sole responsibility of the attorneys-general and their delegates, free of ministerial interference. ${ }^{8}$ Post-1994 the African National Congress (ANC), as ruling party, viewed the 1992 Act with suspicion. It regarded the Act as a political ploy by the outgoing National Party government to entrench the position of the attorneysgeneral, who were representative of the old order. ${ }^{9}$

The ANC successfully pushed for a constitutional provision to establish a national prosecuting authority for South Africa, whose head would be appointed by the president. ${ }^{10}$ The constitutionality of the provision was challenged by a number of provincial attorneysgeneral at the time, on the grounds that it impinged on the separation of powers between the legislature, executive and judiciary. ${ }^{11}$ The Constitutional Court rejected this objection, arguing that the prosecuting authority is not part of the judiciary, and that the appointment of its head by the president does not in itself contravene the doctrine of the separation of powers. ${ }^{12}$

Fears about the NPA's independence from political interference revolved around two related concerns, with the first being the power of the executive - that of the minister of justice in particular - to influence and interfere with the function of the country's chief prosecutor, the National Director of Public Prosecutions (NDPP). ${ }^{13}$ Second, the centralised and hierarchical nature of the NPA endowed the NDPP with considerable power over the provincial Directors of Public Prosecutions (DPPs) and, by implication, all prosecutors in the country. ${ }^{14}$ For example, the NDPP has the authority to intervene in the prosecution process when policy directives are not complied with, ${ }^{15}$ and to review a decision to prosecute or not prosecute, after 'consulting' the relevant DPPs (i.e. the NDPP can overrule his deputies, provided consultation has taken place). ${ }^{16}$
In 1998, then president Nelson Mandela's appointment of Bulelani Ngcuka as the NPA's first head raised concerns among the General Council of the Bar and opposition parties that the NDPP would be a partisan political appointee. ${ }^{17} \mathrm{Ngcuka}$, relatively unknown prior to his appointment, had served as ANC Chief Whip in the National Council of Provinces, following earlier work on the ANC Constitutional Committee and with the United Democratic Front. Ngcuka was, however, well regarded across the political spectrum and considered a hard worker and consensus-builder.

\section{Immediate challenges, new priorities}

On assuming his post in mid-1998 - initially with no staff or even a national office - Ngcuka faced three fundamental challenges: ${ }^{18}$ winning the respect and allegiance of senior prosecutors, many of whom had been appointed during the apartheid era and who had opposed the creation of a centralised prosecution service; raising morale and productivity among junior prosecutors; and building public confidence in the new prosecuting authority. ${ }^{19}$

Some of these challenges were acute. The NPA inherited a fragmented, provincially-based and poorly remunerated prosecution corps, with some offices close to collapse. ${ }^{20}$ For example, between 1994 and 1997 some 630 prosecutors - approximately a third of the total number of prosecutors at the time - resigned countrywide. ${ }^{21}$ Between them they had the equivalent of more than 2000 years of work experience as prosecutors, and their departure inevitably lowered the average experience level of prosecutors. ${ }^{22}$

The establishment of the NPA coincided with a shift in priorities for the criminal justice system. ${ }^{23}$ From 1994 through 1997, government leaders in the justice sector had focused on the transformation of the police and the criminal justice system more broadly. Their goal was to make the justice system more responsive to community concerns, more accountable and democratic, and more focused on some of the underlying drivers of crime, especially socio-economic deprivation. ${ }^{24}$

By 1998, however, with concern about rising violent crime spreading to virtually all communities, 
condemnation of the ineffectiveness of the criminal justice system was widespread. In response, the government adopted a more aggressive approach to combating crime through robust and visible policing, tougher bail laws, severe punishment of criminal offenders, and new enforcement tools to deal with organised crime. ${ }^{25}$ This resulted in a massive increase in arrests and cases of criminal investigations referred to court by the police for prosecutors' attention. ${ }^{26}$ The NPA responded to these challenges in a variety of ways.

\section{Innovation and specialisation}

The NPA's enabling legislation provided the new prosecuting authority with a powerful capacity to combat crime in the form of Investigating Directorates. ${ }^{27}$ Headed by a senior prosecutor, Directorate staff were granted considerable investigative powers. Investigating Directorates were designed to be staffed by a core group of senior prosecutors and detectives, assisted, where necessary, by relevant specialists such as forensic accountants and intelligence personnel. Investigating Directorates were meant to enable prosecutiondriven investigations, ${ }^{28}$ where investigations are conducted under the close guidance and assistance of a senior prosecutor to ensure that evidence collected can be used effectively in court. ${ }^{29}$ Traditionally, prosecutors and investigators in South Africa worked relatively independently of one another in different agencies.

The NPA quickly established three high-profile national Investigating Directorates: for organised crime, serious economic offences, and corruption. ${ }^{30}$ In 2001, these were submerged into a newly created Directorate of Special Operations (DSO), commonly known as the 'Scorpions', focusing on a variety of national priority crimes and organised crime. ${ }^{31}$ With a focus on high-profile cases, the Scorpions were almost immediately a public relations success. Moreover, the new directorate demonstrated the effectiveness of prosecution-driven investigations for successfully prosecuting complex crimes. $^{32}$

Within the first five years of the NPA's existence a number of specialised units were established, permitting prosecutors to develop skills and long- term strategies for combating particularly challenging and pernicious forms of crime. ${ }^{33}$ The first such unit, set up in 1999, was the Asset Forfeiture Unit (AFU), ${ }^{34}$ using South Africa's new forfeiture legislation to pursue the assets of persons involved in organised crime and the proceeds of such crime. Shortly thereafter the Specialised Commercial Crimes Unit (SCCU) ${ }^{35}$ was established with the aim of reducing complex commercial crime and, together with the police, effectively investigating and prosecuting these crimes.

Also in 1999, the Sexual Offences and Community Affairs (SOCA) Unit ${ }^{36}$ was established with the objective of reducing levels of violence against women and children, and minimising the secondary victimisation that victims of sexual offences experience in their dealings with the criminal justice system. SOCA set up the first 'one-stop' Thuthuzela Care Centre for sexual offences victims in 2000. ${ }^{37}$ Now numbering 35 around the country, the Care Centres use a multi-disciplinary approach, involving all the role players necessary for a successful sexual offences investigation and prosecution. ${ }^{38}$ This integrated model has received much international acclaim and is being replicated outside South Africa. $^{39}$

In 2003, the Priority Crimes Litigation Unit was set up to deal with, inter alia, international crimes contained in the Rome Statute of the International Criminal Court, crimes against the state such as terrorism, and matters emanating from the Truth and Reconciliation Commission (TRC) process. ${ }^{40}$

The NPA also established a number of other units and programmes supporting its core prosecutorial function, including corporate services, an Integrity Management Unit, a research office, an Aspirant Prosecutors' Programme, and an Office for Witness Protection. ${ }^{41}$

A division of the NPA dedicated to managing the performance of prosecutors countrywide, the National Prosecuting Service (NPS), was also established. ${ }^{42}$ Through the NPS and a court management unit, the NPA initiated a strategic planning process and the design of a system of performance measurement. It introduced performance targets for individual prosecutors 
and provided enhanced training and a new level of managers (chief prosecutors) to help coordinate and assess the performance of prosecutors.

A further innovative development was the introduction of a 'community prosecution' model, which sought to generate a new range of responses to crime that moved beyond the traditional NPA role of processing and prosecuting cases. ${ }^{43}$ Instead of prosecuting cases in court, the community prosecutor's mission was to reduce and prevent crime, and build relationships and collaborate with the community. ${ }^{44}$

\section{Consolidation and growth}

During the early years of the NPA's existence, Ngcuka and his senior team sought to create a national and unified prosecuting authority; in terms of both structure and management systems and the attitudes of its staff. This was no easy task. At the time of the NPA's creation, the country's (provincial) prosecution services were losing professional staff at an alarming rate because of, inter alia, poor pay and working conditions, many senior white prosecutors' uncertainty about their future, and rapidly rising levels of recorded crime, which not only placed increased burdens on prosecutors but also undermined public confidence in the criminal justice system.

Partly because he was a political insider with an open channel to then president Thabo Mbeki, and partly because of the pressure the government experienced to combat crime, Ngcuka managed to accrue additional resources for the NPA, including salary increases for prosecutors. ${ }^{45}$ With increased funding, the NPA established new senior positions, expanding the number of career paths for prosecutors. Increased specialisation allowed experienced prosecutors to become experts in their fields.

The NPA also removed prosecutors in the lower courts from the de facto day-to-day administrative control of magistrates, contributing to an overall professionalisation of the prosecution service. A new and modern head office building, the rising prominence and success of the Scorpions, and regular nationwide meetings between senior prosecutors to discuss strategy and share good practices, all contributed to an improved image ${ }^{46}$ for the prosecuting authority and a growing esprit de corps for its prosecutors. ${ }^{47}$

As one commentator noted: 'In its first few years the NPA attracted talented lawyers who gave up private sector jobs to join this cool new outfit. Along with the taxman, the NPA was easily the most attractive government agency to work for.' ${ }^{48}$

\section{Performance}

The NPA's performance should be interpreted in the context of an increase in resources, especially in the number of prosecutorial staff. Moreover, the NPA added an additional layer of countrywide supervision to the prosecutorial function, improved and institutionalised training for prosecutors, and enhanced its ability to measure the performance and output of prosecutors. Given these positive changes, it is striking that the data discussed below do not show more sustained and marked improvements in the NPA's performance.

During the first few years of its existence, the NPA had to deal with a massive increase in the number of cases referred to court by the police - from 524000 in 1998 to over a million in 2002 (Figure 1). ${ }^{49}$

Figure 1: Case processing trends, 1996 - 2012/13

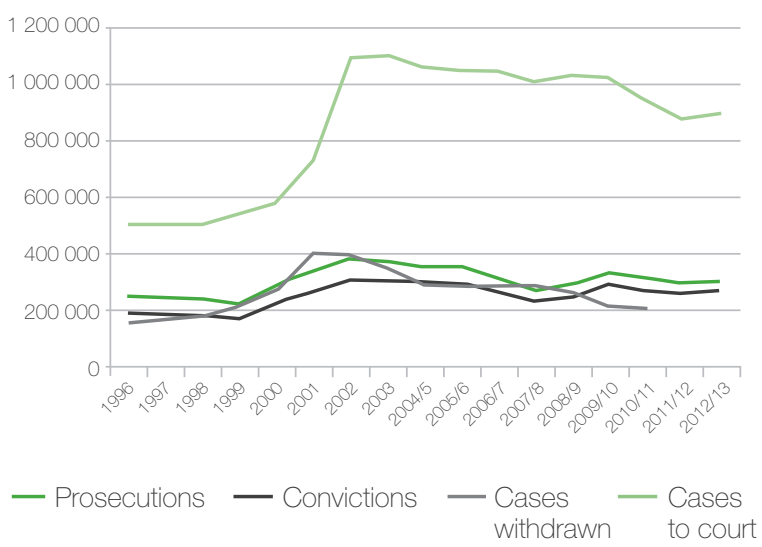

Source: NPA and SAPS annual reports ${ }^{50}$

Between 1999 and 2002, the number of prosecuted cases increased by $62 \%$. It is probably no coincidence that the upward swing in the number of prosecuted cases began shortly after the establishment of the NPA. The NPA employed additional prosecutors shortly after its establishment, 
and succeeded in increasing the number of trial hours in court. ${ }^{51}$ The introduction of Saturday ${ }^{52}$ and additional courts in 2001 also contributed to the increase in the number of finalised cases. ${ }^{53}$

The gradual downward trend in the number of prosecutions after 2002 can be attributed to an increase in the use of alternative dispute resolution mechanisms by the NPA and a decline in the number of cases referred to court. While a negligible number of cases had been resolved through alternative dispute resolution mechanisms in 1998, by 2012/13 these had increased to over $143000 .^{54}$

The overall conviction rate, calculated as the number of cases convicted as a proportion of cases prosecuted, has improved since 1998 (Figure 2). ${ }^{55}$ This is, however, an ambiguous performance indicator. Generally the NPA prosecutes cases only when its prosecutors believe they have a reasonable prospect of obtaining a conviction. By interpreting these criteria to prosecute more restrictively - by withdrawing borderline cases, for example prosecutors are able to improve their chances of obtaining a conviction without any requisite improvement in the skills they devoted thereto.

The steady increase in the number of cases withdrawn by the prosecution service was reversed after 2002. ${ }^{56}$ Nonetheless, the number of cases referred to court and subsequently withdrawn by the NPA remains high, typically in the region of 300000 per year in the decade after 2003. ${ }^{57}$

Figure 2: Conviction rate, 1996 - 2012/13

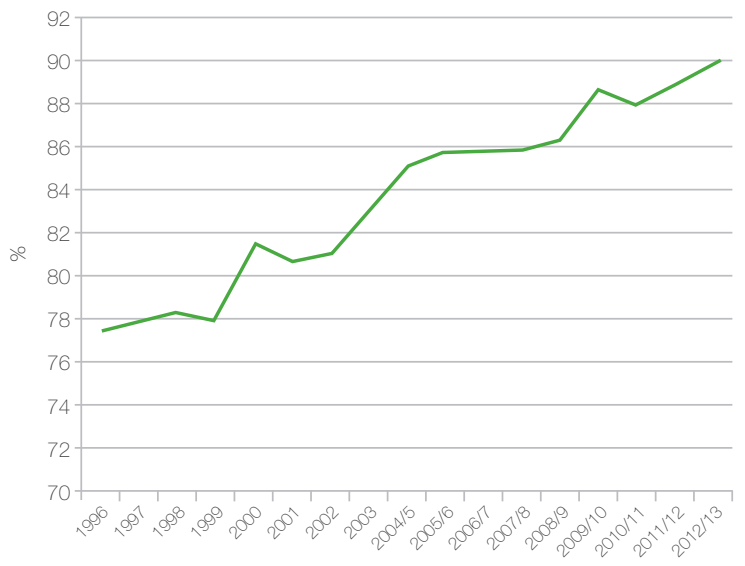

Source: NPA and Department of Justice annual reports ${ }^{58}$
The NPA's achievements have been more pronounced in the output of its specialised units. The DSO, the AFU, the SCCU and the SOCA Unit have, for example, succeeded in maintaining high performance rates in prosecuting complex and serious crimes and, in the case of the AFU, seizing the proceeds of organised crime. ${ }^{59}$

As discussed in the next section, a very small subset of the NPA's successes - investigating and prosecuting high-profile politicians - has resulted in the erosion of its independence. Thus, the NPA's emblematic crime-fighting tool, the DSO, was disbanded after a resolution to this effect was passed at the ANC's annual conference in $2007^{60}$ (see SACQ 24, June 2008).

\section{Politicisation of the NPA}

In 2000, the DSO began a corruption investigation into a multi-billion rand arms procurement package concluded by the South African government in 1999. The primary suspect in the NPA's investigation was Schabir Shaik, a businessman and financial advisor to then deputy president Jacob Zuma. ${ }^{61}$ His brother, Chippy Shaik, was in charge of arms acquisitions at the Department of Defence, which allowed Schabir Shaik to bid on a lucrative contract to supply Corvettes to the South African Navy. ${ }^{62}$ It subsequently transpired that Schabir Shaik was believed to have had a corrupt relationship with Zuma, and that the latter was also a suspect in the investigation. ${ }^{63} \mathrm{In}$ August 2003, Ngcuka announced that despite the existence of a prima facie case against the deputy president, the NPA would not prosecute him. ${ }^{64}$ This went against the advice given to Ngcuka by his team of senior arms deal prosecutors. ${ }^{65}$

Zuma supporters interpreted Ngcuka's announcement as part of a manoeuvre to taint Zuma's reputation: namely, that Ngcuka's decision suggested that Zuma was likely guilty of a crime but that the NPA lacked the necessary evidence to prove guilt beyond reasonable doubt, as would be required in a trial. In the ensuing fallout, Ngcuka was accused of being an apartheid-era spy but was cleared by a commission of inquiry instituted by Mbeki. ${ }^{66}$ In mid-2004, Ngcuka announced his decision to resign, citing personal reasons. ${ }^{67}$ It is likely, however, that the 
debacle around Ngcuka's decision not to prosecute Zuma, a critical report by the Public Protector on that decision, and the spying allegations all contributed to Ngcuka's decision. ${ }^{68}$

The above developments occurred in the context of a power struggle between two factions within the ANC, aligned behind Mbeki on the one side and Zuma on the other.

In the interim, the case against Schabir Shaik had gone ahead. Upon Schabir Shaik's conviction in mid-2005, Mbeki announced that Zuma would be relieved of his government duties because of the latter's relationship with Shaik, as found in the court judgement. ${ }^{69}$

This context is important as it provides the first indication that the NPA could be misused in an intraparty political power struggle in the ANC - fissures that were to affect and divide the NPA profoundly in the years thereafter. ${ }^{70}$

In 2005, Vusi Pikoli succeeded Ngcuka as NDPP. ${ }^{71}$ Under Pikoli's leadership, emboldened by the Schabir Shaik conviction, the NPA charged Zuma with various counts of racketeering, money laundering, corruption and fraud. ${ }^{72} \mathrm{~A}$ conviction and sentence of imprisonment exceeding one year - highly likely upon conviction on such serious charges - would have rendered Zuma ineligible for election to Parliament and thereby to serve as the country's president. This was a direct threat to Zuma's ambitions, as he had been elected as head of the ANC in late 2007.

Also under Pikoli's leadership, the NPA determined to prosecute the then national commissioner of police, Jackie Selebi, a perceived ally of Mbeki, on corruption charges. ${ }^{73}$ Shortly after the existence of a warrant for the arrest of Selebi became known, Mbeki suspended Pikoli on the basis of an 'irretrievable breakdown' in the relationship between Pikoli and the justice minister. ${ }^{74}$ While a commission of inquiry subsequently found that most of the allegations against Pikoli were unfounded, Parliament endorsed Pikoli's suspension. ${ }^{75}$ Pikoli's dismissal had a chilling effect on the NPA and was a deeply demoralising experience for prosecutors who saw in him a disciplined and principled leader. ${ }^{76}$
The political meddling in the affairs of the NPA by the country's executive, and the impact this had on the organisation, is a matter of public record. The various machinations are sufficiently numerous and complex to fill a book. ${ }^{77}$ Space does not permit a detailed exposition here; suffice to make the following abbreviated points:

- Ngcuka was NDPP for six years (the law provides for a 10-year tenure for an NDPP). ${ }^{78}$ After his departure, the NPA entered a period of instability, infighting and public controversy, all of which continue to this day. Since August 2004, the NPA has had six different NDPPs (of which three served in an acting capacity) ${ }^{79}-$ an average of less than two years per NDPP or acting NDPP. This led to numerous changes in the strategy and organisational priorities of the NPA.

- Within the NPA's senior leadership, pro-Mbeki and pro-Zuma factions developed, affecting staff morale and unduly influencing senior appointments and promotions. ${ }^{80}$ Often a form of institutional stalemate ensued with numerous senior positions filled by 'acting' appointees who lacked the security permanent appointment would provide. This state of affairs has had an arguably debilitating effect on the NPA's organisational effectiveness, and diverted institutional energy to internecine conflicts at the expense of focusing on the organisation's mission.

- As a consequence of, inter alia, the DSO's success in investigating, among others, senior MPs implicated in the 'Travelgate' scandal, ${ }^{81}$ and politicians involved in the arms deal, notably Zuma and Selebi, the enthusiasm the ruling party's members of Parliament and the executive held for the DSO 'waned substantially'. ${ }^{22}$ This resulted in the disbandment of the DSO and the loss of a significant crime-fighting tool in the NPA's armoury.

- On application of the opposition Democratic Alliance, the Constitutional Court found that Menzi Simelane, who was appointed as NDPP in late 2009 by President Zuma, was not a fit and proper person to be NDPP, thus effectively overturning the President's appointment. ${ }^{83}$ For the head of a relatively young organisation (the NPA had been in existence for 13 years at the time Simelane's appointment was set aside by the courts) to 
be branded unsuitable to his position invariably undermined public confidence in the organisation and underscored the political nature of the NDPP's appointment.

- Badly conceptualised and politically motivated decisions by the NPA have resulted in the courts reviewing NPA decisions to discontinue prosecutions in a select number of high-profile cases. ${ }^{84}$ If this becomes a trend, it can result in the NPA being bogged down in costly and timeconsuming litigation in the years ahead, being asked to justify why it declined to prosecute in specific cases. This is not to question the courts' authority to review, under certain circumstances, prosecutorial decisions not to prosecute, but it is an indictment of the NPA that its traditionally wide-ranging discretion to decline to prosecute is coming under increasing judicial scrutiny.

The disappointing aspects of the NPA's performance are especially glaring in the context of the growth in the number of prosecutorial staff over the past decade, and better pay and working conditions. It is possible that areas of poor performance have been exacerbated by the political and politicised crises the NPA has been embroiled in for the greater part of its existence.

Shortly after the Supreme Court of Appeal set aside Simelane's appointment as NDPP for being 'inconsistent with the constitution and invalid', 85 and the NPA's withdrawal of corruption and fraud charges against Richard Mdluli, head of crime intelligence in the police (a decision which the courts subsequently set aside), ${ }^{86}$ one commentator wrote in early 2012 :

The NPA is a flicker of its old self, plagued by internal power battles, witch-hunts and pungent odours of political influence. Good prosecutors are leaving in droves, I am told, and those who stay keep their mouths shut and follow orders. ${ }^{87}$

\section{Conclusion}

After its establishment in 1998, the NPA rapidly drew together the provincial attorneys-general's offices into one national organisation. In short order, the new organisation set up the DSO with its multi-disciplinary, prosecution-driven approach to investigations, and established specialised units in the office of the NDPP. It also created new positions to enhance the career choices of prosecutors, professionalised the management of the NPA's growing staff, and devoted time and effort to improving the NPA's image among the public through innovative approaches such as 'community prosecution' and public outreach efforts.

The positive changes have had the most measurable impact on the performance of the NPA's specialised units. The NPA's performance at the lower or magistrate's court level, where the vast majority of all prosecutions occur and where most public interactions with the prosecution service take place, are more mixed.

Time will tell whether the NPA is able to extract itself from its present malaise. It has the resources and infrastructure, and many dedicated prosecutors to do so. To fulfil its constitutional mandate to prosecute 'without fear, favour or prejudice', a principled and dedicated core of senior NPA leaders is indispensable. The NPA will need leaders who are committed to upholding the Constitution and, by implication, the rule of law.

As gatekeepers to the criminal justice system, prosecutors are the system's most powerful officials. Prosecutors decide whether criminal charges should be brought and what those charges should be. In South Africa, prosecutors exercise considerable discretion in making those crucial decisions. Politicians the world over, particularly those in powerful executive positions, will always be tempted to interfere in prosecutorial decisions, especially where they are the subject of investigations and possible prosecution. Whether blatant political interference or subtle pressure - and the NPA has suffered plenty of both - the best line of defence is prosecutors themselves, who need to be beyond reproach.

To comment on this article visit http://www.issafrica.org/sacq.php 


\section{Notes}

1 Martin Schönteich, The South African Prosecution Service, in J Steinberg (ed.), Crime wave: the South African underworld and its foes, Johannesburg: Witwatersrand University Press, 2001; Martin Schönteich, Lawyers for the people: the South African Prosecution Service, Institute for Security Studies (ISS), Monograph 53, 2001, http://www.issafrica. org/publications/monographs/monograph-53-lawyers-forthe-people-the-south-african-prosecution-service-by-martinschonteich; Martin Schönteich, NPA in the dock: thumbs up for the prosecution service, SA Crime Quarterly 3 (March 2003), 29-32, http://www.issafrica.org/publications/southafrican-crime-quarterly/south-african-crime-quarterly-3/ npa-in-the-dock-thumbs-up-for-the-prosecution-servicemartin-schonteich; Anton du Plessis, Jean Redpath and Martin Schönteich, Report on the South African National Prosecuting Authority, in Promoting prosecutorial accountability, independence and effectiveness, Sofia: Open Society Institute, 2008; Martin Schönteich, Strengthening prosecutorial accountability in South Africa, ISS, Paper 255, April 2014, http://www.issafrica.org/publications/papers/ strengthening-prosecutorial-accountability-in-south-africa.

2 Dirk van Zyl Smit and Esther Steyn, Prosecuting Authority in the New South Africa, Centre for the Independence of Judges and Lawyers Yearbook, VIII (January 2000), 144.

3 PM Bekker, National or super attorney-general: political subjectivity or judicial objectivity?, Consultus 8(1) (April 1995), 27; ZB du Toit, Groot agterdog heers oor die 'superprokureur-generaal', Rapport, 9 February 1997.

4 For example, at the time of the constitutional negotiations the issue of the measure of control exercised by the NDPP over the provincial DPPs was controversial and 'the outcome was a compromise'. See William A Hofmeyr, Confirmatory and supporting affidavit, S v Zuma and Others NPD, CC 273/07 (8652/08), para 10.

5 For a detailed historical discussion, see Schönteich, Lawyers for the people, 31-33.

6 The Supreme Court was established in 1909. All provincial divisions of the Supreme Court had an office of the provincial attorney-general, as did some of the court's local divisions (e.g. Witwatersrand, Eastern Cape) but not others (e.g. Durban and Coast). The Interim Constitution, which came into force in 1994, retained the structure of the Supreme Court, but absorbed the supreme courts of the homelands as provincial divisions. The 'final' Constitution, which came into force in 1997, transformed the provincial and local divisions into high courts.

7 Attorney-General Act 1992 (Act 92 of 1992), Pretoria: Government Printer. The Act came into operation on 31 December 1992.

8 In terms of section 4 of the Attorney-General Act, an attorney-general needed to vacate his office only on attaining the age of 65 years (unless the president extended this for a maximum of two years). Moreover, an attorney-general could be suspended and removed from office, by the president or at the request of both houses of Parliament in the same session, only on the grounds of misconduct, continued illhealth or incapacity to carry out his duties of office efficiently. In an instance where the president suspended an attorneygeneral, both houses of Parliament could overrule the president's suspension.
9 In 1994 the newly appointed Minister of Justice, Dullah Omar (ANC), stated that the office of the attorney-general lacked accountability and had been an instrument of the apartheid state. In 'the dying days of apartheid' the independence of the office of the attorney-general was introduced. This, Omar concluded, was not done so much to guarantee independence as to entrench the status quo. See Omar plaas vraagteken oor 'PG's van apartheid', Die Burger, 14 November 1994.

10 Constitution of the Republic of South Africa 1996 (Act 108 of 1996), Pretoria: Government Printer, section 179(1)(a).

11 Du Toit, Groot agterdog heers oor die 'super-prokureurgeneraal'.

12 See Ex Parte Chairperson of the Constitutional Assembly: in re certification of the Constitution of the Republic of South Africa, 19961996 (4) SA 744 (CC).

13 While the Constitution endows the prosecuting authority with considerable functional and legal independence from the executive, there is room for ambiguity in the way the relevant constitutional provisions are to be interpreted. Section 179(2) of the Constitution empowers the prosecuting authority 'to institute criminal proceedings on behalf of the state' and 'to carry out any necessary functions incidental to instituting criminal proceedings'. Moreover, section 179(4) demands that prosecutors exercise their functions 'without fear, favour or prejudice'. Section 179(5) implies that the NDPP is on an equal footing with the minister of justice, as the NDPP must determine prosecuting policy 'in concurrence' with the minister. That is, while the minister has to consent to any policy that is to come into effect, the minister cannot unilaterally impose his will on the NDPP. On the other hand, section 179(6) contains an ambiguous provision that the minister of justice is 'responsible for the administration of justice' and 'must exercise final responsibility over the prosecuting authority'. This seemingly undermines some of the prosecuting authority's independence. Moreover, section 179(1)(a) provides that the NDPP is appointed by the president in his capacity as 'head of the national executive'.

14 Bekker, National or super attorney-general, 27.

15 Constitution of the Republic of South Africa, section 179(5)(c).

16 Ibid., section 179(5)(d). To review a decision to prosecute or not to prosecute, the NDPP must 'consult' the relevant provincial DPPs. Thus, while the NDPP must take into account the DPPs' comments, he need not abide by their recommendations. According to Van Zyl Smit and Steyn, the power to review a decision to prosecute or not to prosecute 'appears to exist even where policy directives are being followed'. See Dirk van Zyl Smit and Esther Steyn, Prosecuting authority in the new South Africa, Paper prepared for workshop of experts on the review of criminal justice in Northern Ireland, Belfast, 9 June 1999, 9.

17 The General Council of the Bar expressed its reservations about Ngcuka's appointment: 'The appointment of Ngcuka underscores our objections to the [National Prosecuting Authority] Bill. It is clear he is a party-political man who could be susceptible to political influence.' See H Barrell and M Soggott, Nice guy, but can he do the job?, Mail \& Guardian, 17 June 1998; Douglas Gibson, The independence of the judiciary compromised?, Press Release, 16 July 1998.

18 Christopher Stone, Cheslan America and Michelle India Baird, Prosecutors In the front line: increasing the effectiveness of 
criminal justice in South Africa, Bureau of Justice Assistance and the Vera Institute of Justice, 2003 (unpublished document), 7 .

19 Ibid., 7.

20 Ibid., 7.

21 Telephonic interview with JJ Swart, president of the National Union of Prosecutors of South Africa, 7 April 1997.

22 Hansard [NA:Q] no. 6, col. 874, 16 April 1998. In 1995 there was a $40 \%$ turnover of prosecutors at the Johannesburg Magistrate's Court (see P Naidoo, Justice chaos: advocates start work-to-rule campaign, Cape Argus, 14 July 1996). At the Durban Magistrate's Court about one-third of prosecutors had resigned in the 18 months between the beginning of 1995 and June 1996 (see L Seeliger, Durban's courts in crisis, The Natal Mercury, 20 June 1996).

23 See Eric Pelser and Janine Rauch, South Africa's criminal justice system: policy and priorities, Paper presented at the South African Sociological Association (SASA) Annual Congress on Globalisation, Inequality and Identity, 1-4 July 2001; and Gareth Newham, A decade of crime prevention in South Africa: from a national strategy to a local challenge, Centre for the Study of Violence and Reconciliation, 2005, www.csvr.org.za/docs/crime/decadeofcrime.pdf (accessed 3 June 2014).

24 Newham, A decade of crime prevention in South Africa, 4-5.

25 For a discussion of this shift in government policy and law enforcement strategy, see Martin Schönteich, Criminal justice policy and human rights in the New South Africa, Law and Justice Journal 3(2) (2003).

26 Schönteich, Lawyers for the people, 117.

27 National Prosecuting Authority Act 1998 (Act 32 of 1998), Pretoria: Government Printer, section 28, as amended.

28 Jean Redpath, The Scorpions: analysing the Directorate of Special Operations, ISS, Monograph 96, 2004, 63-65.

29 National Prosecuting Authority Act, section 28.

30 Respectively, the Investigating Directorate: Organised Crime and Public Safety; Serious Economic Offences; and Corruption. For a discussion of their powers and functions, see Schönteich, Lawyers for the people.

31 National Prosecuting Authority Amendment Act 2000 (Act 61 of 2000), Pretoria: Government Printer, sections 1 and 20. See also Redpath, The Scorpions, 44-49.

32 For a history of the DSO, its legislative and operational mandates, and performance, see Redpath, The Scorpions.

33 For a discussion of the benefits of specialisation and the history of the Asset Forfeiture Unit (AFU) and the Sexual Offences and Community Affairs (SOCA) Unit, see Schönteich, Lawyers for the people.

34 AFU, National Prosecuting Authority, http://www.npa.gov.za/ ReadContent387.aspx (accessed 4 June 2014).

35 Antony Altbeker, Justice through specialisation? The case of the Specialised Commercial Crime Court, ISS, Monograph 76, 2003, 4, http://www.issafrica.org/publications/ monographs/monograph-76-justice-through-specialisationthe-case-of-the-specialised-commercial-crime-court-antonyaltbeker (accessed 1 June 2014).

36 SocA Unit, National Prosecuting Authority, http://www.npa. gov.za/ReadContent412.aspx (accessed 30 September 2014).
37 National Prosecuting Authority, Thuthuzela: turning victims into survivors, undated brochure, http://www.npa.gov.za/ ReadContent529.aspx (accessed 30 September 2014).

38 Ibid.

39 United Nations Children's Fund (UNICEF), Rolling out the Thuthuzelas, undated, http://www.unicef.org/southafrica/ protection_5084.html (accessed 18 April 2014).

40 Priority Crimes Litigation Unit (PCLU), National Prosecuting Authority, http://www.npa.gov.za/ReadContent405.aspx (accessed 30 September 2014).

41 Iole Matthews, The National Prosecuting Authority, in Chandré Gould (ed.), Criminal (in)justice in South Africa, Pretoria: ISS, 2009, 99; Office for Witness Protection, National Prosecuting Authority, http://www.npa.gov.za/ ReadContent390.aspx (accessed 30 September 2014).

42 National Prosecution Service (NPS), National Prosecuting Authority, http://www.npa.gov.za/ReadContent389.aspx (accessed 30 September 2014).

43 See Matthews, The National Prosecuting Authority, 109-114.

44 Vusi Pikoli, Beyond prosecutions: community prosecutions, Paper delivered at the International Association of Prosecutors Conference (IAP), Paris, 27-31 August 2006.

45 Interview with an erstwhile senior advisor to Bulelani Ngcuka, Cape Town, 1 March 2013.

46 Martin Schönteich, NPA in the dock: thumbs up for the prosecution service, SA Crime Quarterly 3 (March 2003), 29-32.

47 Interviews with prosecutors of varying ranks and in a variety of locations in 2001-2002.

48 How the NPA lost its way, City Press, 11 February 2012, http://www.citypress.co.za/columnists/how-the-npa-lost-itsway-20120211/ (accessed 12 April 2014).

49 The data for the years 1996-1999 is from the SAPS' Crime Information Analysis Centre, while the 2000-2003 data was obtained by the author from the NPA's Court Management Unit.

50 The data has been compiled from various annual reports produced by the NPS (http://www.npa.gov.za/) and the South African Police Service (SAPS) (http://www.saps.gov. za/about/stratframework/annualreports_arch.php).

51 Ted Leggett et al., Criminal justice in review 2001/2002, ISS, Monograph 88, 2003, 45, http://www.issafrica.org/ publications/monographs/monograph-88-criminal-justicein-review-20012002-ted-leggett-antoinette-louw-martinschonteich-and-makubetse-sekhonyane (accessed 10 February 2014).

52 Courts that are open and conduct business on a Saturday.

53 Bureau of Democracy, Human Rights, and Labor, South Africa: 2003 Country reports on human rights practices, Washington DC: Department of State, http://www.state. gov/j/drl/rls/hrrpt/2003/27752.htm (accessed 14 July 2014); Wyndham Hartley, South Africa: backlogs under control, says Ngcuka, Business Day, 29 October 2002, http://allafrica. com/stories/200210290820.html (accessed 14 July 2014).

54 Mxolosi Nxasana, National Director of Public Prosecutions, Presentation to the Portfolio Committee on Justice and Constitutional Development, 8 October 2013, Cape Town. See also Hema Hargovan, A balancing act for the 
prosecutor: restorative justice, criminal justice and access to justice, SA Crime Quarterly 42 (December 2012), 13-20.

The data has been compiled from various annual reports produced by the NPS (http://www.npa.gov.za) and, before 1999, by the Department of Justice (the latter are on file with the author). See also Leggett et al, Criminal justice in review 2001/2002, 42.

56 For a discussion of the various reasons why cases are withdrawn see Schönteich, Lawyers for the people, 93-94.

57 The high withdrawal rate or prosecutors' decision not to prosecute in a sizeable proportion of cases has been criticised. A 2012 review of the NPA found that 'prosecutorial decision to decline to prosecute is both specifically and systematically exercised to such an extent that proportionally fewer cases are placed on the court roll each year and fewer still are brought to trial. The best indication of this is that the number of verdicts and the number of persons sentenced to prison show a general decline.' The review concluded that, as the decline in the number of prosecutions coincided with an increase in NPA resources, especially in respect of prosecutor and staff numbers, it is the 'efficiency per prosecutor in terms of cases prosecuted [that] has declined'. See Jean Redpath, Failing to prosecute? Assessing the state of the National Prosecuting Authority of South Africa, ISS, Monograph 186, 2012, vi, http://www.issafrica.org/ publications/monographs/failing-to-prosecute-assessing-thestate-of-the-national-prosecuting-authority-in-south-africa (accessed 15 April 2014).

58 The data has been compiled from various annual reports produced by the NPS (http://www.npa.gov.za/) and, before 1999, by the Department of Justice (the latter are on file with the author).

59 See, for example, NPA, Annual report 2012/2013, 29-34, 36-37, 56-58; NPA, Annual report 2011/2012, 22-26, 38-40, 43-44, 48-49; and NPA, Annual report 2010/2011, 24-28, 32-34, http://www.npa.gov.za/ (accessed 30 September 2014).

60 African National Congress, $52^{\text {nd }}$ National Conference: Resolutions, 20 December 2007, http://www.anc.org.za/ show.php?id=2536 (accessed 20 September 2014).

61 Andrew Feinstein, Paul Holden and Barnaby Pace, Corruption and the arms trade: sins of commission, in SIPRI Yearbook 2011: armaments, disarmament and international security, New York: Oxford University Press, 2011, 24-25.

62 Ibid., 24-25.

63 Answering affidavit by Johan du Plooy, para 15, 9 July 2008 , in The State vs Jacob Zuma \& Others re. 'The application by accused no. 1 for an order reviewing and setting aside the decision to prosecute him', High Court Of South Africa Natal Provincial Division, CC 273/07 (8652/08).

64 C Johnson, Zuma not to be prosecuted, The Mercury, 27 August 2003.

65 Improper not to prosecute JZ: prosecutions chiefs blamed for Zuma impasse, Mail \& Guardian, 1 October 2010, http:// mg.co.za/article/2010-10-01-improper-not-to-prosecute-jz (accessed 20 September 2014).

66 Commission of Inquiry into allegations of spying against the National Director of Public Prosecutions, Mr BT Ngcuka (the Hefer Commission).
67 Ngcuka: Did he jump ... or was he pushed?, IOL News, 26 July 2004, http://www.iol.co.za/news/politics/ngcuka-didhe-jump-or-was-he-pushed-1.218031\#.VDDLHVelqRQ (accessed 20 September 2014).

68 Sally Archibald, Ngcuka was not 'robust enough', Mail \& Guardian, 26 July 2004, http://mg.co.za/article/2004-07-26ngcuka-was-not-robust-enough (accessed 20 September 2014).

69 Department of International Relations and Co-operation, Statement of the President of South Africa, Thabo Mbeki, at the Joint Sitting of Parliament on the Release of Hon Jacob Zuma from his Responsibilities as Deputy President: National Assembly, 14 June 2005, http://www.dfa.gov.za/ docs/speeches/2005/mbek0614.htm (accessed 10 February 2014).

70 See, for example, Sam Sole, Thabo's boys vs Vula's boys - the sequel, Mail \& Guardian, 15 December 2011, http:// mg.co.za/article/2011-12-15-thabos-boys-vs-vulas-thesequel (accessed 15 April 2014).

71 Pikoli was appointed as NDPP in January 2005. Silas Ramaite was acting NDPP from September to December 2005.

72 National Director of Public Prosecutions v Zuma (573/08) [2009] ZASCA 1 (12 Jan 2009), para 5.

73 NPA ready to charge Selebi, Moneyweb, 11 January 2008, http://www.moneyweb.co.za/moneyweb-political-economy/ npa-ready-to-charge-selebi (accessed 20 September 2014).

74 Mbeki suspends NDPP's Vusi Pikoli, IOL News, 24 September 2007, http://www.iol.co.za/news/politics/mbekisuspends-ndpp-s-vusi-pikoli-1.371979\#.VC1jl1elqRQ (accessed 24 September 2014).

75 Pikoli removed from office, vows to fight back, Mail \& Guardian, 17 February 2009, http://mg.co.za/article/200902-17-pikoli-removed-from-office-vows-to-fight-back (accessed 22 September 2014).

76 How the NPA lost its way, City Press, 11 February 2012, http://www.citypress.co.za/columnists/how-the-npa-lost-itsway-20120211/ (accessed 12 April 2014); interviews with NPA prosecutors of various ranks in Gauteng, KwaZulu-Natal and the Western Cape in late 2012.

77 Some publications cover aspects of the NPA's tribulations vis-à-vis political interference and politically motivated (non) prosecutions. See, for example, Adriaan Basson, Zuma exposed, Cape Town: Jonathan Ball Publishers SA, 2012; and Vusi Pikoli and Mandy Wiener, My second initiation: the memoir of Vusi Pikoli, Johannesburg: Picador Africa, 2013.

78 National Prosecuting Authority Act, section 12(1).

79 Namely, Bulelani Ngcuka (July 1998 - August 2004); Silas Ramaite, acting (September - December 2004); Vusi Pikoli (January 2005 - September 2007); Mokotedi Mpshe, acting (September 2007 - November 2009); Menzi Simelane (December 2009 - December 2011); Nomgcobo Jiba, acting (December 2011 - September 2013); and Mxolisi Nxasana (October 2013 - present).

80 For example, in July 2012, the acting head of the NPA in KwaZulu-Natal, Simphiwe Mlotshwa, was replaced by Advocate Moipone Noko-Mashilo. At the time, concerned NPA staff thought the unexpected removal of Mlotshwa could pave the way for 'political interference' in the high-profile fraud and corruption case involving several 
elected provincial ANC officials. See Glynnis Underhill, Staff smell a rat in NPA rotation, Mail \& Guardian, 20 July 2012, http://mg.co.za/article/2012-07-19-staff-smell-arat-over-national-prosecuting-authority-rotation (accessed 28 September 2014). In August 2012, Noko-Mashilo announced the withdrawal of criminal charges against KZN Economic Development MEC Mike Mabuyakhulu and KZN Legislature Speaker Peggy Nkonyeni. See Ingrid Oellerman, Amigos: corruption charges withdrawn, The Witness, 2 October 2012, http://www.witness.co.za/ index.php?showcontent\&global[_id]=88574 (accessed 28 September 2014). Noko-Mashilo's appointment as provincial DPP was made permanent by Zuma in September 2013.

81 For an overview of the 'Travelgate scandal', see Gareth van Onselen, 7 of the worst: how the ANC rewards corruption, www.inside-politics.org, http://inside-politics. org/2012/06/27/7-of-the-worst-how-the-anc-rewardscorruption/ (accessed 2 October 2014).

82 Loammi Wolf, Pre- and post-trial equality in criminal justice in the context of the separation of powers, Potchefstroom Electronic Law Journal 14(5) (2011), 91.

83 Democratic Alliance $v$ President of South Africa and Others (CCT 122/11) [2012] ZACC 24; 2012 (12) BCLR 1297 (CC); 2013 (1) SA 248 (CC) (heard on 8.05.2012).

84 See, for example, Democratic Alliance v The Acting National Director of Public Prosecutions (288/11) [2012] ZASCA 15 (15 February 2012); National Director of Public Prosecutions v Freedom Under Law (67/14) [2014] ZASCA 58 (17 April 2014).

85 Democratic Alliance $v$ The President of the RSA \& Others 2012 (1) SA 417 (SCA). The SCA's judgement was confirmed, on appeal, by the Constitutional Court on 5 October 2012.

86 National Director of Public Prosecutions v Freedom Under Law.

87 How the NPA lost its way, City Press, 11 February 2012, http://www.citypress.co.za/columnists/how-the-npa-lost-itsway-20120211/ (accessed 12 April 2014). 